\title{
Development-induced Displacement and Homelessness in Seattle, Washington
}

\author{
Veronica Fynn Bruey*
}

\section{Abstract}

As big technological companies expand across the Seattle Metropolitan area, real estate construction is exploding in downtown Seattle where homelessness due to development-induced displacement is concerning. To this end, the internal displacement of vulnerable populations, including Indigenous peoples, homeless persons, and refugees is mainly due to large scale development of big tech companies. The indifference of using the term "internal displacement" to describe the situation of development-induced displacement makes it difficult to identify, name and raise the agenda of developmentinduced displaced homeless people in the area. Thus, the goal of this paper is to present a general overview and assessment of the state of development-induced displacement of homeless peoples in Seattle due to big companies' expansion, so as to initiate and stimulate critical dialogue on furthering research in the area.

Keywords: Development Induced Displacement, Seattle, Homelessness and Housing, Economic Development

\section{Introduction}

Under the crust of that portion of Earth called the United States of America, from California to the Gulf Stream waters - are interred the bones, villages, fields, and sacred objects of American Indians. They cry out for their stories to be heard through their descendants

*Seattle University School of Law, USA; fynnbruv@seattleu.edu 
who carry the memories of how the country as founded and how it came to be as it is today (Dunbar-Ortiz, 2014, p. 1).

Beginning the history of the United States of America in 1776 as exceptional example of liberty, sovereignty, and morality (Wood, 2009, p. 7) is unacceptable and deceptive. As with Christopher Columbus terra nullius (land without people) classic historical distortion, the United States is one of settler colonialism based on imperialism, slavery, racism and discrimination characterised by violence, land dispossession and subsequently, displacement of the First Peoples(Tucker, 1857, pp. 22-23). Roxanne Ortiz affirms that, "the history of the United States is a history of settler colonialism, the founding of a state based on the ideology of white supremacy, the widespread practice of African slavery, and a policy of genocide and land theft" (Dunbar-Ortiz, 2014, p. 2). The city of Seattle in Washington State is no exception to this historical saga.

Proponents of settler-colonist historical "doctrine of discovery" myth (Jenkins, 2003, p. 1; Permanent Forum on Indigenous Issues, 2012) claim that Seattle was founded in 1851 (City of Seattle Archives, 2018). The Duwamish Peoples, who are the original dwellers and only Indigenous group native to metropolitan Seattle area, have been inhabiting the Seattle area long before 1851 (Allain, 2014, p. 16). Although the fact remains that, "[e]very American city is built on Indian land, [only] few advertise it like Seattle" (Thrush, 2017, p. 3). Manhole covers are embellished with Tlingit Orca totems, car ferries are named Klickitat and Elwha, the Port of Seattle marina is called Shilshole, the Seahawk logo, and of course, a public art display of Chief Si'ahlraising a welcoming hand at the Seattle Center Monorail (Thrush, 2017, p. 3). At the same token, Seattle is a city which has a long history of displacing indigenous peoples since the early arrival of the white settler-colonists.

Seattle, the largest city in Washington, is located on the eastern shore of the Puget Sound with an estimated 704,352 people (United States Census Bureau, 2018). The total population of Seattle comprises 69.2 per cent White, 14.1 per cent Asian, 7.1 per cent Black or African American, 6.6 per cent Hispanic or Latino, 0.6 per cent American Indian and Alaska Native, and 0.4 per cent Native Hawaiian and other Pacific Islander (United States Census Bureau, 2018). 
Previously perceived as a conservative town built on the lumber, shipping, and aircraft industries, today Seattle is a hub for the manufacturing, technology and the real estate industries.

According to Frederic Grant, "all Europeans know that life in America is easier and labour more profitable than in their native land, and this very knowledge is operating, and always will operate, to relax their natural love of home and country, and bring them hither" (Grant, 1891, p. 16). Stanley Engerman and Robert Gallman observe that Europeans practices of capital accumulation and market production is completely foreign to Native Americans (Engerman \& Gallman, 1996, p. 1). Albeit, it is this incessant desire for profit that is spiralling contemporary Seattle into a city of economic wealth and growth, notwithstanding, at the expense of increasing homelessness, which ultimately results in developmentinduced displacement of various minority populations.

Accurate global statistics on homelessness are unavailable or nonexistent. It is estimated that about two per cent (150 million) of the world's population are homeless (Chamie, 2017). According to the United Nations Habitat, 1.6 billion people lack affordable housing, yet the same number of people will require adequate housing by 2025 (UN Habitat, 2016, p. 51). In the United States, on a single night in January 2017, 553,742 people were experiencing homelessness (Henry, Watt, Rosenthal, Shivji, \& Abt Associates, 2017, p. 8). Of these, 21 per cent $(114,829$ people) were children, 61 per cent $(335,038$ people) men, and 39 per cent $(215,709$ people) women. Regarding race, 47 per cent $(260,979$ people) identified as white, 41 per cent (224,937 people) African American, seven per cent $(35,745$ people) multiple races, three per cent (16,796 people) Native American, two per cent (8,724 people) Pacific Islander, and one per cent (6,760 people) Asian (Henry et al., 2017, p. 9).

For ethnicity, the 2017 Annual Homeless Assessment Report provides only two categories: Non-Hispanic and Hispanic or Latino. Seventy-eight per cent $(434,323$ people) of homeless people identified as non-Hispanic and 22 per cent (119,419 people) as Hispanic or Latino (Henry et al., 2017, p. 9). Overall, 65 per cent of homeless individuals were sheltered and 35 per cent unsheltered (Henry et al., 2017, p. 8). Of the sheltered individuals, 35 per cent were individuals whilst 30 per cent were people living in families. 
For unsheltered homeless persons, 32 per cent were individuals compared with three per cent that were not (Henry et al., 2017, p. 8). The United States Department of Housing and Urban Development (HUD) statistical analysis of national population does not include identification of homeless people, refugees, immigrants or people with disability.

The most recent Seattle/King County Point-In-Time Count of Persons Experiencing Homelessness (2018) report shows a four per cent increase in homelessness from 2017. On the night of the 2018 Pointin-Time Count in Seattle/King County (Count-Us-In Seattle/King County), 12,112 people were identified as experiencing homelessness with an estimated 3,552 experiencing chronic homeless (i.e., people sleeping in places not meant for human habitation) (DeWolf et al., 2018, pp. 8, 11). Amongst the six counties in King County, Seattle shows the highest number (70 per cent or 4,488 people) of homeless persons whilst the Southeast County was the lowest (one per cent or 70 people) (DeWolf et al., 2018, p. 10).

Seventy per cent of the Count-Us-In Seattle/King County respondents reported living in their own home were renting prior to becoming homeless, whilst 98 per cent said they would move into affordable and safe housing if it were provided (DeWolf et al., 2018, p. 13). Of the total Count-Us-In Seattle/King County, 48 per cent $(5,792)$ were sheltered while 52 per cent $(6,320)$ were not. An estimated 2,624 people were individuals with children representing 782 families, 1,518 unaccompanied youths and young adults, 921 veterans, and 3,372 were people living in their vehicles (DeWolf et al., 2018, pp. 11-12). Homelessness impacts people of colour disproportionately as the largest disparities identifies Black or African American in the Count-Us-In Seattle/King County (2018). Approximately 48 per cent of individuals in the Count-Us-In Seattle/King County identify as white, 27 per cent as Black/African American, six per cent as Native American or Pacific Islander, and 16 per cent as multiple races. Regarding ethnicity, 15 per cent of homeless individuals identifies as Hispanic or Latino (DeWolf et al., 2018, pp. 12, 21).

Officials of several Native Organizations providing services to Native Americans experiencing homelessness in Seattle/King County refuted findings of the Count-Us-In Seattle/King County 
report (2018). Colleen Echohawk, Executive Director of Chief Seattle Club asserts that, "[t]his report claims that half of our homeless population is now living in housing compared to last year, but at Chief Seattle Club, membership increased by 17 percent in 2016 and another 14 percent in 2017" (Staff Reporter, 2018). Abigail Echo-Hawk, Director of Urban Indian Health Institute emphasised that, "[f]rom the start, the methodologies they [CountUs-In Seattle/King County] used to gather this data was not going to accurately reflect the number of homeless Native people in this county because they simply were not surveying the right locations...This is unacceptable and only creates more problems and harm for a marginalised community" (Staff Reporter, 2018).

\section{Definition and Conceptual Framework of Development- Induced Displacement}

Undeniably, as big technological companies expand, real estate explodes in downtown Seattle. Studies have shown a positive correlation between increase housing prices and homelessness. To this end, the internal displacement of vulnerable populations, including homeless people in Seattle due to large scale development of big tech companies is an apparent growing concern. Unfortunately, the extremely low academic materials available on the topic significantly reflect the lack of interest in using the term "internal displacement" to describe the situation of development-induced displacement in Seattle and by implication the United States and Western society. The few academic resources related to the topic of development-induced displacement and the experience of homelessness in Seattle tend to use the words, "gentrification", "resettlement" and "integration" (McGee, Jr., 2007). It is within such limited access and context to resources that the definition, conceptual framework and analysis of the article draw heavily on sources outside of Seattle and online newsprint to carve out a descriptive examination of the topic at stake.

\subsection{Displacement}

Displacement is a multi-dimensional framework with physical relocation being a crucial consequences (Sharma, 2016, p. 21). The term "displaced persons" was first coined by Eugene M. Kulischer 
in 1943, which at the time included all forms of forced movement and involuntary resettlement in Europe during World War II (Terminski, 2013, p. 7). Five decades later, the Guiding Principles on Internal Displacement 1998 (the Guiding Principles) defines internally displaced persons (IDPs) as:

persons or groups of persons who have been forced or obliged to flee or to leave their homes or places of habitual residence, in particular as a result of or in order to avoid the effects of armed conflict, situations of generalized violence, violations of human rights or natural or human-made disasters, and who have not crossed an internationally recognized state border. (Deng, 1998)

Although, the Guiding Principles does not explicitly include development-induced displacement in its definition of IDPs it does "fill a major gap in the international protection system for uprooted peoples" affected by social, economic, political, civil, and cultural aspects of return, resettlement and reintegration (Cohen, 2004, pp. 465, 476).

Principle 6(1) of the Guiding Principles states that "[e]very human being shall have the right to be protected against being arbitrarily displaced from his or her home or place of habitual residence". Principle 6(2)(c) of the Guiding Principles asserts that the prohibition of arbitrary displacement includes "cases of large-scale development projects, which are not justified by compelling and overriding public interests." Further, Principle 9 of the Guiding Principles oblige States to "protect against the displacement of indigenous peoples, minorities, peasants, pastoralists and other groups with a special dependency on and attachment to their lands." It is within the purview of Principle 6 of the Guiding Principles that the concept of development-induced displacement is applied in this article.

\subsection{Development-induced displacement}

At the core of development-induced displacement, the word "development" functions as the driving force in the uprooting of people from their ancestral homelands to which they have built ties and bonds for centuries (Lone, 2014, p. 218). Earlier concepts of development favoured modernisation theory that transformed 
societies in capital-intensive, projected to accelerate better future. A new paradigmatic shift indicates that development can also promote poverty, destroy the environment, and instil injustice (Robinson, 2003, p. 10). Seen as a cost-benefit theory, involuntary displacement of marginalised populations from their places of habitual residence is the utmost cost of large-scale development projects, hence the term "development-induced displacement". It is worth pointing out that a preferred phrase, "development induced displacement and resettlement", is not the same as developmentinduced displacement, which encompasses a much broader concept of general displacement irrespective of whether or not a resettlement program accompanies the ensued displacement (Satiroglu, 2015, p. 3).

\subsection{Homeless Person and Homelessness}

The United States (US) Department of Housing and Urban Development (HUD) describes a homeless person as an individual "who lacks a fixed, regular, and adequate nighttime residence" (Henry et al., 2017, p. 2). While euphemisms such as "no fixed abode" are commonly used to describe homelessness, the terms "homelessness" of "homeless" are as diverse as the people themselves (Kissoon, 2015, p. 1). Despite the variety of meanings and experiences, the concept of homelessness is strongly associated with a "middle-aged single alcoholic male, resident in alleyways or city shelters, and "squeegee-kids" who have run away to the streets and survive on small transactional acts" in large urban cities (Kissoon, 2015, pp. 1-2).

Roslyn Arlin Mickelson believes that homelessness and concerns of homeless persons are not simply a single individual phenomenon but rather one of social class and status (Mickelson, 2000, pp. 2627). In his conceptual framework, Michael Cernea includes homelessness, whether temporary or chronic, amongst eight impoverishment risks in affirming that forced migration is embedded in economic and social uprooting of vulnerable populations (Cernea, n.d., pp. 1572-1573). Jason Stanley identifies urban infrastructure and transportation projects that include "slum clearance and upgrading, the establishment of industrial and commercial estates, the building and upgrading of sewerage 
systems, schools, hospitals, ports, etc." as causes of developmentinduced displacement (Stanley, 2011, sec. 3.2).

At the crux of Cernea and Jason's model is the fact that homelessness resulting from development-induced displacement is not a voluntary act, instead it is "an operation of physically relocating [vulnerable] people" (Dwivedi, 2002, p. 716) and "impoverishing them" (McDowell, 1996, p. 51) that characterise the coercive and involuntary nature of such forced migration. For example, in Seattle, the conscious operation of urban development and transportation projects that leave people homeless does not only disrupt the lives of persons that are compelled to vacate their places of habitual abode, but it also leaves the environment and its surroundings worst-off (De Wet, 2006, p. Back Cover).

\subsection{Gentrification}

Ruth Glass first coined the term "gentrification" in 1964 when referring to "demographic shifts within an urban community" of London's Islington community (Murray, 2017, p. 3). Glass' description of the process of gentrification pinpoints displacement as a key factor:

One by one, many of the working-class quarters have been invaded by the middle class - upper and lower ... Once this process of 'gentrification' starts in a district it goes on rapidly until all or most of the working-class occupiers are displaced and the whole social character of the district is changed. (Glass \& Univesity College, London Centre for Urban Studies, 1964, p. xvii)

In other words, gentrification means the process of change a neighbourhood undergoes when wealthier, mostly white, newcomers and investors take over by displacing vulnerable people (Murray, 2017, p. 3). Seattle Fair Growth adds that "gentrification is the process of renewal and rebuilding that accompanies the influx of middle-class or affluent people into lower-class, often deteriorating, neighbourhoods...actively changing the physical, socioeconomic, and demographic characteristics of neighbourhoods most specifically by displacing poorer residents" (Lisbin, 2018). In spite of some positive outcomes (e.g. lower crime rate), the adverse impact of gentrification on 8 
vulnerable populations is profound. For example, forced displacement of single mothers with children, people with disabilities and the elderly; who are unable to afford the cost of living in a gentrified neighbourhood may be forced to relocate to a community that is unsafe, poor and inhabitable (Lisbin, 2018).

Glass' explanation above shows that gentrification is a type or a subset of displacement (Glass \& Univesity College, London Centre for Urban Studies, 1964, p. 3) that is associated with increased housing or rental prices, property taxes and residential incomes. However, Kathleen Murray's perspective of gentrification (above) fails to capture the involuntary or forced displacement aspects of gentrification. In fact, Zuk et al., reveal that most researchers "narrowly defined [residential] displacement as evictions or unaffordable prices increases" or gentrification and this observation is mainly due to the limited resources or research on the issue of internal displacement in the United States (Zuk et al., 2015, p. 27).

\subsection{Resettlement}

Home Link defines resettlement as "the move a homeless person make from temporary housing or the streets into more permanent, often independent, accommodation"(The Innovation and Good Practice Team, 2013, p. 2). Central to Home Link's definition of resettlement is the issue of housing, which is the main reason the United States adopts a model known as "Housing First" when addressing homelessness. The HUD describes the Housing First model as

An approach to quickly and successfully connect individuals and families experiencing homelessness to permanent housing without preconditions and barriers to entry, such as sobriety, treatment or service participation requirements. Supportive services are offered to maximize housing stability and prevent returns to homelessness as opposed to addressing predetermined treatment goals prior to permanent housing entry. (United States Department of Housing and Urban Development Exchange, 2018, p. 1)

A longitudinal study conducted in London of 400 single homeless people over 18 months reported that the "use of temporary 
accommodation prior to being resettled and the duration of stay had a strong influence on tenancy sustainment" (Crane, Warnes, \& Coward, 2012, p. 17). That is, homeless people who stayed in temporary housing for 12 months before being resettled had the highest chance of gaining permanent tenancy (Crane et al., 2012, p. 17). Carol McNaughton Nicholls and Iain Atherton argue that even though there is no obligation on a homeless person to comply with requirements for supportive services needed to make them "housing ready" permanently, the housing first model is an essential human right component for successful resettlement of people experiencing homelessness with multiple needs (Nicholls \& Atherton, 2011, p. 767).

\section{6 (Social) Integration}

Like gentrification and resettlement, integration of homeless peoples is at a crucial intersection of involuntary displacement and access to housing. In a simple term, integration is the mixing of homeless people with the rest of society in order to encourage their participation and inclusion into local community life (Gouvernement de Québec, 2017). Supporting social integration of people experiencing homelessness allows for harmonious coexistence thereby creating a sense of belonging (Gouvernement de Québec, 2017). Colin Morrison and Todd Belt explore three dimensions of integration on marginalised groups: physical, psychological and social (Morrison \& Belt, 2014, p. 2). With higher incidence and prevalence to mental health, drug abuse, discrimination and racism, and other related health problems; social inclusion and reinforcement of effective intervention programs must underpin the integration of homeless peoples into their local communities (Bergheul, 2018).

According to Morrison and Belt, physical integration measures the degree of physical presence and contexts of a marginalised person in ordinary settings (Morrison \& Belt, 2014, p. 2). Psychological integration is the extent to which an individual perceives his or her membership in a marginalised sub-group compared to the broader society (Morrison \& Belt, 2014, p. 3). Social integration encompasses the number of social interactions within a vulnerable group against society at large (Morrison \& Belt, 2014, p. 3). Morrison and Belt 
suggest that existence of the three types of integration among homeless peoples could mean that they may have the propensity to imitate those in a housed population to attract the perception of normalcy (Morrison \& Belt, 2014, p. 3).

On the other hand, Priya Kissoon identifies two indicators of social integration. They are functional indicators: employment, housing, education and language acquisition; and affective indicators: belonging citizenship, and nationalism (Kissoon, 2015, p. 16). Kissoon argues that homelessness is indicative of extreme outcomes of poor functional integration or poor affective integration (Kissoon, 2015, p. 16). A study done by Jack Tsai, Alvin S. Mares, and Robert A. Rosenheck found that more efforts need to be put in developing rehabilitation programs that support housing for chronically homeless peoples to improve social integration outcomes (Tsai, Mares, \& Rosenheck, 2012, p. 427). A housing first approach in dealing with high and complex need of homelessness is also affirmed by Deborah Quilgers (Quilgars\& Pleace, 2016, p. 5). So, how is Seattle, a home to big companies, fairing when it comes to housing homeless peoples? First, let's consider the state of economic development of big companies in Seattle.

\section{Economic Development: Big Companies in Seattle}

Girded by Boeing, Amazon and Microsoft, the State of Washington ranks \#1 in economic activity in the United States with a GDP of $\$ 506$ billion, a median income of $\$ 67,106$ and an investment per capita of \$154 in 2017 (Jackson, Lee, Lin, \& Ratnatunga, 2018, p. 22; Nickelsburg, 2018). In 2016, the Seattle Metropolitan Area had a Gross Domestic Product of $\$ 330,409$ million, 90 per cent $(\$ 295,876)$ of which comes from private industries (US Department of Commerce Bureau of Economic Analysis, 2017). Top employers in the Seattle/King County area include a number of Fortune 500 companies (Economic Development Council of Seattle and King County, 2015).

Table 1: Top Companies in King County/Seattle 


\begin{tabular}{|c|c|c|c|c|c|}
\hline \multicolumn{3}{|c|}{$\begin{array}{l}\text { Largest Employers in King } \\
\text { County }\end{array}$} & \multicolumn{3}{|c|}{$\begin{array}{c}\text { Fortune } 500 \text { Companies in King } \\
\text { County }\end{array}$} \\
\hline$\#$ & $\begin{array}{l}\text { Employer } \\
\text { Name }\end{array}$ & $\begin{array}{l}\text { Full-Time } \\
\text { Employees }\end{array}$ & Company & City & $\begin{array}{l}\text { Net } \\
\text { Income } \\
\text { (in } \\
\text { millions) }\end{array}$ \\
\hline 1 & Boeing & 81,919 & $\begin{array}{l}\text { Costco } \\
\text { Wholesale }\end{array}$ & Issaquah & 116,199 \\
\hline 2 & Microsoft & 43,031 & Amazon & Seattle & 107,006 \\
\hline 3 & $\begin{array}{l}\text { University of } \\
\text { Washington }\end{array}$ & 30,200 & Microsoft & Redmond & 93,580 \\
\hline 4 & Amazon & 24,700 & Starbucks & Seattle & 19,163 \\
\hline 5 & $\begin{array}{l}\text { King County } \\
\text { Government }\end{array}$ & 13,400 & Paccar & Bellevue & 19,115 \\
\hline 6 & Starbucks & 11,239 & Nordstrom & Seattle & 14,437 \\
\hline 7 & $\begin{array}{l}\text { Swedish } \\
\text { Health } \\
\text { Services }\end{array}$ & 10,758 & Weyerhaeuser & $\begin{array}{l}\text { Federal } \\
\text { Way }\end{array}$ & 7,082 \\
\hline 8 & $\begin{array}{l}\text { City of } \\
\text { Seattle }\end{array}$ & 10,080 & Expedia & Bellevue & 6,672 \\
\hline 9 & $\begin{array}{l}\text { Costco } \\
\text { Wholesale }\end{array}$ & 9,264 & $\begin{array}{l}\text { Expeditors } \\
\text { International } \\
\text { of Washington }\end{array}$ & Seattle & 6,617 \\
\hline 10 & Nordstrom & 8,982 & $\begin{array}{l}\text { Alaska } \\
\text { Airlines }\end{array}$ & Seattle & 5,598 \\
\hline 11 & $\begin{array}{l}\text { Group } \\
\text { Health } \\
\text { Cooperative }\end{array}$ & 7,271 & & & \\
\hline
\end{tabular}

Source: Economic Development Council of Seattle and King County, (2015) available at http://www.edc-seaking.org/service/economic-data/economic-basics

With some 558,023 people employed in civilian labour force (Office of Economic Development, 2018) and an unemployment rate of 3.9 per cent as at March 2018 (Bureau of Labor Statistics, 2018, p. 1), the wage gap between white native-born and minority group in the Seattle area is evident (Davis et al., 2017, pp. 3, 5, 7-8). For example, hourly wages for human resources managers (\$63.16), computer programmers (\$59.76), and Civil Engineers (\$44.74) - a majority of whom are white native-born are two to three times more than retail salespersons (\$17.18), cashiers (\$14.14), Cooks/fast foods (\$13.62), and personal care aides (\$13.45), who are mostly immigrants, refugees and naturalized Americans (Bureau of Labor Statistics, 
2018, p. 2; Davis et al., 2017, p. 26). The wage gap between White American-born population and other vulnerable peoples help drive the homeless and housing problems in Seattle despite its relatively high economic development. Moreover, it is worth noting that Seattle high economic growth is strongly tied to gentrification, a major ingredient of development-induced displacement.

\subsection{Amazon}

From 2011 - 2016, Amazon invested more than $\$ 100$ billion in the US adding $\$ 45$ billion to the US economy. In 1994, Amazon started with three people in Jeff Bezos' garage. Today, Amazon provides 125 jobs per day in the US, with over 45,000 employed in Seattle alone and more than 600,000 new jobs created for small businesses selling Amazon products. Amazon plans to create an additional 100,000 full-time positions with full-benefit in the US by mid-2018. Approved by the Downtown Planning Department, Amazon purchased land in downtown Seattle for \$207 million (Anderson, 2018, p. 7) to build its $\$ 4$ billion Amazon Spheres (González, 2017).

The Amazon Spheres, "an extensive collection of biodiversity" are home to more than 40,000 plants and 400 different species from over 30 countries (Amazon, 2018b). In May 2017, Amazon announced that half of its newest six-story office building will include a homeless shelter that can accommodate as many as 65 families (Murray, 2017, p. 2; Wamsley, 2017). By way of community engagement and healthy eating, at it's South Lake Union or Denny Regrade neighbourhoods in Seattle, Amazon "Banistas" hand out as many as 5,000 fruits per day to passers-by and strollers (Amazon, 2018a).

\subsection{Microsoft}

Headquartered in Redmond a suburb of Seattle, Microsoft was founded in 1975 and is a global leader in software, services, devices and solutions that help people and businesses realize their full potential (Microsoft Corporation, 2018). With its Technology Centers situated in Bellevue, Microsoft appears to be dwarfed by Amazon expansion in Downtown Seattle (Levy, 2016). Besides injecting $\$ 59.7$ billion into Washington State economy as a top employer, Microsoft employs 47,679 persons within the Puget 
Sound area with a total labour income impact of $\$ 21.6$ billion in 2016 (Microsoft Corporation, 2017, p. 2).

Not only are many of Microsoft employees immigrants from around the globe, but the company is also one of the largest philanthropic organizations in the United States and the world (Eicher, 2010, pp. 2-3; B. Hurst \& Radke, 2015). For example, in 2015, Microsoft donated $\$ 10$ million to the University of Washington to establish the Bill \& Melinda Gates Center for Computer Science and Engineering (Microsoft Corporation, 2017, p. 2). In 2017, Microsoft also donated $\$ 10$ million to the University of Washington to set up the Paul G. Allen Center for Computer Science and Engineering (Microsoft Corporation, 2017, p. 2). Since 2011, Microsoft has donated \$35 million to the Washington State Opportunity Scholarship, a public-private scholarship that helps low- and middle-income residents earn degrees in science, technology, engineering, math and healthcare (Microsoft Corporation, 2017, p. 2).

\subsection{Google}

"[T]o organise the world's information and make it universally accessible and useful" (Tran, 2017, p. 5), co-founders, Larry Page and Sergey Brin, then students at Stanford University founded BackRub, which was later incorporated as Google in 1998 (Handel, 2014, pp. 11-13; Kuntze \& Matulich, 2010, p. 2). With some 60,000 employees worldwide, Google makes hundreds of products used by billions of people across the globe, including YouTube, Android, Smartbox, and Google Search (Google, 2018). In 2016, Google moved its offices from Freemont to a six-story 607,000 square feet building in South Lake Union (Bishop, 2016; Levy, 2017; Stiles \& Stewart, 2016). Although Google is headquartered in Mountain View, California, employees in the Freemont, Kirkland, and Seattle areas of Washington rose from 1,900 in 2016 to 3,000 in 2018 (Levy, 2018). Unfortunately, limited research information on Google in Seattle, prevents similar presentation of its community engagement and social activities as done with Amazon and Microsoft above.

In spite of Seattle/King County's blossoming economy, several factors determine whether many homeless families will ever achieve economic stability i.e., accessing gainful employment, 
quality education and housing. Securing and holding a decent job with say Amazon, Microsoft or Google, is key but a far-fetched goal to economic stability for homeless peoples. Having gainful employment supports a range of processes of social integration for homeless peoples: secure and stable housing, access to social benefits and social capital, public safety, and civic engagement. Albeit, a city inundated with industrial and technological expansion in the face of rising homelessness creates a perfect recipe for institutional and social barriers that undermine the full integration of homeless people to adopt a Housing First model.

\section{Housing and Homelessness in Seattle: Economy, Development and Impact}

Investment, job creation and healthy engagement with community members are all good economic growth strategies, provided wealth distribution is inclusive and benefitted by all, especially the homeless in Seattle. For instance, "Amazon has moved up in the real estate game, now occupying a massive urban campus in the heart of Seattle" (Anderson, 2018, p. 6). By June 2016, there were 65 major buildings under construction in the surrounding neighbourhoods of downtown Seattle and South Lake Union, with dozens of more buildings to begin construction by the end of 2017 (Anderson, 2018, p. 6). A relatively higher number of real estate construction more than any point since tracking began in 2005, Amazon has more than one-third of the office space under construction in the downtown Seattle area. As a city with one of the fastest rising home prices and rents in the US, in 2017, apartment rents in Seattle were 63 percent higher than had been in 2010, and home prices doubled since 2012 (Anderson, 2018, p. 6). The sprawling housing and real estate development with big companies in Seattle is not exclusive to Amazon. Facebook, Expedia, and Google are also expanding and adding their own developments into the mix. The local government in Seattle recently initiated an effort to engage big companies in helping to address the homeless/housing problem.

Back in 2009, the City Council proposed the Employees Hours Tax ("Head Tax") on 10 per cent of businesses in Seattle with a gross income of at least $\$ 5$ million per year $\left(\mathrm{O}^{\prime}\right.$ Brien \& Harris-Talley, 
2017 , p. 2). The purpose of levying an additional $\$ 0.05$ an hour per employee on some 2,200 businesses was to help reduce displacement caused by economic and development growth in Seattle, thereby providing a solution to the homeless problem (O'Brien \& Harris-Talley, 2017, p. 2). Unfortunately, the law was repealed due to the recession at the time but reintroduced in 2017. By May 2018, Amazon halted its construction planning of a new tower in downtown Seattle pending a vote by the City Council on the "Head Tax" to fund homelessness program (Day \& Beekman, 2018; Hobbes, 2018). An amended or "scaled-back" (Scruggs, 2018) tax was passed unanimously with all nine council members supporting. Highlights from the amended ordinance include (Seattle City Council, 2018):

- Exempt Seattle's small and medium-sized businesses, only applying to those with at least $\$ 20$ million or more annually in taxable gross receipts as measured under the City's existing Business \& Occupation tax;

- Apply only to the City's approximately 585 largest businesses, or approximately $3 \%$ of all Seattle businesses;

- Require large businesses to pay $\$ 275$ per full-time equivalent employee working 1,920 hours per year (or about $\$ 0.14$ per hour);

- Include an evaluation of the economic impacts, and an independent oversight committee; and,

- Exempt healthcare providers that provide at least $25 \%$ of their services to patients covered by Medicare and Medicaid as well as all hospitals.

Barely a month after unanimously voting in favour of the "Head Tax", the Seattle City Council reversed its vote to repeal the employee hours tax, pleasing big businesses but leaving the growing housing crisis unsolved (Hsieh, 2018).

There are over 140,000 affordable housing units needed to help curb the homeless problems in Seattle (Seattle City Council, 2018). To date, the City of Seattle has funded and built 12,419 affordable housing units through its non-profit partners (Seattle City Council, 2018). The amended business tax was earmarked to generate $\$ 75$ 
million/year, 75 per cent ( $\$ 57$ million) of which would have built 1,780 deeply affordable housing units over a five-year period, 20 per cent (\$15 million/year) for emergency and shelter services for people experiencing homelessness (Seattle City Council, 2018). Now, any chance of addressing the chronic housing problem in Seattle is jeopardised.

\section{Housing Affordability}

Washington is the tenth most expensive state for renters in the United States with a Fair Market Rent for a two-bedroom apartment set at \$1,229 per month (National Low Income Housing Coalition, 2017). To afford this kind of rent, a household must earn an hourly wage of $\$ 23.64$ (i.e., $\$ 4,098$ monthly) or work 86 hours per week at the minimum wage of $\$ 11.00$ (National Law Income Housing Coalition, 2017, pp. 252-255; National Low Income Housing Coalition, 2017). As the third-largest population of homeless people in America, King County/Seattle has worse per capita homelessness than New York or Los Angeles (Greenstone, 2018), that is if counting is done accurately (Glynn \& Fox, 2017, pp. 5-6). In concrete terms, in Seattle, a 5 percent average rent increase in 2016 would add 258 people to the homeless population for a total of 12,498 (Glynn \& Allison, 2017).

\section{Conclusion}

Seattle, in the State of Washington and the seat of King County, is one of the fastest growing cities in the United States. Named after Chief Si'ahl, a Native American, Seattle has a long history of using large-scale development projects to involuntarily displace vulnerable populations. Homeless persons are one of the member communities of such a population. As the third-largest population of homeless people in America, King County/Seattle has worse per capita homelessness than New York or Los Angeles. In most recent times the on-going expansion of big companies, such as Amazon, Microsoft and Google, adversely impact real estate and housing, thus heightening development-induced displacement of homeless persons in Seattle. This paper presents a general overview and assessment of the state of development-induced displacement of homeless peoples in Seattle due to big companies' expansion. 
Unfortunately, the extremely low number of academic materials available on the topic of development-induced displacement in Seattle, Washington explains, in part, the reliance on newsprints, reports and other non-academic sources outside the scope of Seattle, Washington. To this end, the paper concludes with a callout to scholars to engage scholars with expertise in this area to initiate critical dialogue and stimulate discussion on furthering research on development-induced displacement in Seattle, Washington and by implication across the United States.

\section{References}

Allain, J. A. (2014). Duwamish history in Duwamish Voices: Weaving our family stories since colonization (PhD Thesis). University of Victoria, Victoria, BC.

Amazon. (2018a). About Amazon [Text and images]. Retrieved May 28, 2018, from https://www.aboutamazon.com/

Amazon. (2018b). Explore the Plants [Text and images]. Retrieved from https://www.seattlespheres.com/the-plants

Anderson, S. (2018). The Amazon grows in Seattle. Urban Journal, 4, 6-11.

Bergheul, S. (2018, May 14). Homelessness: criminalization or social integration? Policy Options, Special Feature. Retrieved from http://policyoptions.irpp.org/magazines/may-2018/homelessnesscriminalization-or-social-integration/

Bishop, T. (2016). Google to move to new 4-building complex in Amazon's backyard in Seattle, developed by Paul Allen's Vulcan Inc. GeekWire. Retrieved from https://www.geekwire.com/2016/paul-allensvulcan-develop-huge-complex-google-amazons-backyard/

Bureau of Labor Statistics. (2018, May 2). Seattle Area Economic Summary. United States Government. Retrieved from https://www.bls.gov/regions/west/summary/blssummary_seattle. pdf

Cernea, M. (1997). The risks of reconstruction model for resettling displaced populations. World Development, 25(10), 1569-1587.

Chamie, J. (2017, July 13). As cities grow worldwide, so do the numbers of homeless. YaleGlobal Online. Retrieved from https:// yaleglobal.yale.edu/content/cities-grow-worldwide-so-do-numbershomeless 
City of Seattle Archives. (2018). Brief History of Seattle [Text and images]. Retrieved from https://www.seattle.gov/cityarchives/seattlefacts/brief-history-of-seattle

Cohen, R. (2004). The guiding Principles on Internal Displacement: An Innovation in International Standard Setting. Global Governance: A Review of Multilateralism and International Organizations, 10(4), 459-480.

Crane, M., Warnes, A. M., \& Coward, S. (2012). Preparing homeless people for independent living and its influence on resettlement outcomes. European Journal of Homelessness, 6(2), 17-45.

Davis, G. S., Klaeysen, C., Richburg, K., Kaz, D., Fynn Bruey, V., Faaren, L., ... Nguyen, V. (2017). Breaking Barriers and Building Bridges: Career Pathways to Economic Stability and Quality Jobs for Seattle's Immigrant and Refugee Workers and Professionals (p. 80). Seattle, WA: City of Seattle Office of Immigrant and Refugee Affairs. Retrieved from https://www.seattle.gov/Documents/Departments/OIRA/Breaking BarriersandBuildingBridges.pdf

Day, M., \& Beekman, D. (2018, May 2). Amazon issues threat over Seattle head-tax plan, halts tower construction planning. The Seattle Times. Retrieved from https://projects.seattletimes.com/ 2018/business/ amazon-mayMap/

De Wet, C. J. (Ed.). (2006). Development-induced Displacement: Problems, Policies and People. New York, NY: Berghahn Books.

Deng, F. M. (1998). Report of the Representative of the Secretary-General: Guiding Principles on Internal Displacement (Economic and Social Council Report No. E/CN.4/1998/53/Add.2) (p. 14). New York, NY: Office of the United Nations High Commissioner for Human Rights.

DeWolf, Z., Putnam, M., Salcedo, F., Van, T., Winslow, D., Yafali, J.-P., ... Valdez, M. (2018). Seattle/King County Point-In-Time Count of Persons Experiencing Homelessness (NGO) (p. 140). Seattle, WA: All Home and Applied Survey Research. Retrieved from http://allhomekc.org/wpcontent/uploads/2018/05/FINALDRAFTCOUNTUSIN2018REPORT-5.25.18.pdf

Dunbar-Ortiz, R. (2014). An Indigenous Peoples' History of the United States. Boston, MA: Beacon Press.

Dwivedi, R. (2002). Models and methods in development-induced displacement (Review Article). Development and Change, 33(4), 709732. https:/ / doi.org/10.1111/1467-7660.00276

Economic Development Council of Seattle and King County. (2015). King County Economy [Text and images]. Retrieved from http://www.edc-seaking.org/service/economic-data/economicbasics 
Eicher, T. S. (2010). The Microsoft Economic impact study (Private) (p. 21). Seattle, WA: Department of Economics, University of Washington. Retrieved from http://richardsdavis.typepad.com/files/msimpact_public.pdf

Engerman, S. L., \& Gallman, R. E. (1996). The Cambridge economic history of the United States. Cambridge, UK: Cambridge University Press. Retrieved from http:/ /dx.doi.org/10.1017/CHOL9780521394420

Glass, R., \& University College, London Centre for Urban Studies. (1964). Aspects of Change. London, UK: MacGibbon and Kee.

Glynn, C., \& Allison, M. (2017, August 3). Rising rents mean larger homeless population. Zillow Research. Retrieved from https://public.tableau.com/views/Homelessness_5/Homeless?:emb ed=y\&:display_count=yes\&:showVizHome=no\#1

Glynn, C., \& Fox, E. B. (2017). Dynamics of homelessness in urban America. ArXiv:1707.09380 [Stat], 1-54.

González, Á. (2017, January 3). Amazon's Spheres: Lush nature paradise to adorn $\$ 4$ billion urban campus. The Seattle Times. Retrieved from https://www.seattletimes.com/business/amazon/amazons-spheresare-centerpiece-of-4-billion-effort-to-transform-seattles-urban-core/

Google. (2018). Our story: From the garage to the Googleplex [Text and images]. Retrieved June 16, 2018, from https:// www.google.com/ about/our-story/

Gouvernement de Québec. (2017, February 22). Integrating homeless people [Government]. Retrieved from http://sante.gouv.qc.ca/ en/ conseils-et-prevention/favoriser-l-integration-des-personnes-ensituation-d-itinerance/

Grant, F. J. (1891). History of Seattle, Washington with Illustrations and biographical sketches of some of its prominent men and pioneers. New York, NY: American Publishing and Engraving Co.

Greenstone, S. (2018, January 16). Is Seattle's homeless crisis the worst in the country? The Seattle Times. Retrieved from https:// www.seattletimes.com/seattle-news/homeless/is-seattles-homelesscrisis-the-worst-in-the-country/

Handel, K. (2014). Case Study: Google, 2014 (Private) (p. 51). Maryville, TN: Maryville College. Retrieved from https:// static1.squarespace.com/ static/56de2285b6aa609ba7f3d1f1/t/56df62b759827e604389a5fe/1457 480375878/Google+Case+Study_Full+Final+Draft.pdf

Henry, M., Watt, R., Rosenthal, L., Shivji, A., \& Abt Associates. (2017). The 2017 Annual Homeless assessment report (AHAR) to Congress (p. 100). Washington, DC: US Department of Housing and Urban 
Development. Retrieved from https://www.hudexchange.info/ resources/ documents/2017-AHAR-Part-1.pdf

Hobbes, M. (2018, May 12). How Amazon is holding Seattle hostage. Huffington Post. Retrieved from https://www.huffingtonpost.com/ entry/amazon-holding-seattle-hostage_us_5af5ba76e4b032b10bfa4285

Hsieh, S. (2018, June 12). Amazon wins: Seattle City Council votes to repeal head tax. The Stranger. Retrieved from https:// www.thestranger.com/slog/2018/06/12/27509559/seattle-citycouncil-votes-to-repeal-head-tax

Hurst, B., \& Radke, A. (2015, November 20). How has 30 years Of Microsoft Windows changed The Northwest? Morning Edition. Retrieved from http://kuow.org/post/how-has-30-years-microsoftwindows-changed-northwest

Jackson, J., Lee, J., Lin, M. C. Y., \& Ratnatunga, M. (2018). Best-Performing Cities: Where America's Jobs are created and sustained (p. 57). Washington, DC: Milken Institute. Retrieved from http://www.bestcities.org/best-performing-cities-2017-large-cities-rankings.html

Jenkins, P. (2003). A History of the United States (2nd ed.). Basingstoke, UK: Palgrave Macmillan.

Kissoon, P. (2015). Intersections of displacement: refugees' experiences of home and homelessness. Newcastle upon Tyne, UK: Cambridge Scholars Publishing.

Kuntze, R., \& Matulich, E. (2010). Google: Search for value. Journal of Case Research in Business and Economics, 2, 1-10.

Levy, N. (2016, December 14). Will Microsoft leave Seattle? How Amazon's growth could force the region's other tech giant out of the urban core [Text and images]. Retrieved June 9, 2018, from https://www.geekwire.com/2016/is-microsoft-leaving-seattle-forgood/

Levy, N. (2017, June 7). Google exec: New Seattle building 'is going to be basically Google Cloud.' GeekWire. Retrieved from https://www.geekwire.com/2017/google-exec-new-seattle-buildinggoing-basically-google-cloud/

Levy, N. (2018, March 9). Google scoops up more tableau office space, now up to $3 \mathrm{~K}$ Seattle-area employees. GeekWire. Retrieved from https://www.geekwire.com/2018/google-scoops-tableau-officespace-now-3k-seattle-area-employees/

Lisbin, I. (2018). Gentrification and displacement [Text]. Retrieved June 1, 2018, from http:/ / www.seattlefairgrowth.org/displacement.html 
Lone, R. A. (2014). Development induced displacement. Journal of Social Science Research, 3(4), 9.

McDowell, C. (Ed.). (1996). Understanding Impoverishment: the consequences of development-induced displacement. Providence, RI: Berghahn Books.

McGee, Jr., W. H. (2007). Gentrification, Integration or Displacement?: The Seattle Story. Retrieved May 18, 2018, from http:// www.blackpast.org/perspectives/gentrification-integration-ordisplacement-seattle-story

McNaughton Nicholls, C., \& Atherton, I. (2011). Housing first: Considering components for successful resettlement of homeless people with multiple needs. Housing Studies, 26(5), 767-777. https://doi.org/10.1080/02673037.2011.581907

Mickelson, R. A. (Ed.). (2000). Children on the Streets of the Americas: Homelessness, Education, and Globalization in the United States, Brazil, and Cuba. London, UK: Routledge.

Microsoft Corporation. (2017). Microsoft Redmond Campus fact sheet. Microsoft Corporation. Retrieved from https://news.microsoft.com/ uploads/2017/11/Microsoft-Redmond-Campus-Fact-Sheet.docx

Microsoft Corporation. (2018). Facts about Microsoft [Text and images]. Retrieved June 9, 2018, from https:/ / news.microsoft.com/facts-aboutmicrosoft/

Morrison, C. S., \& Belt, T. L. (2014). Social integration and political ideologies of the homeless. Journal of Social Research and Policy, 5(1), 524.

Murray, K. (2017). Gentrification: issue. SAGE Business Researcher. Retrieved from http://businessresearcher.sagepub.com/sbr-1863103843-2833123/20170828/gentrification

National Law Income Housing Coalition. (2017). Out of reach 2017: The High Cost of Housing (NGO) (p. 282). Washington, DC: National LowIncome Housing Coalition. Retrieved from http://nlihc.org/ sites/ default/files/oor/OOR_2017.pdf

National Low-Income Housing Coalition. (2017). How much do you need to earn to afford a modest apartment in your state? [Text and images]. Retrieved May 30, 2018, from http://nlihc.org/oor

Nickelsburg, M. (2018, April 21). Washington state's economy ranked highest in the nation despite relatively low investment per capita. GeekWire. Retrieved from https:// www.geekwire.com/ 2018/ washington-states-economy-ranked-highest-nation-despite-relativelylow-investment-per-capita/ 
O’Brien, M., \& Harris-Talley, K. (2017). Employees hours tax ("Head Tax") Homes Proposal. City of Seattle. Retrieved from https://www.seattle.gov/Documents/Departments/Council/Memb ers/OBrien/HOMES-Proposal-One-Pager.pdf

Office of Economic Development. (2018). Jobs: employment estimates [Text and images]. Retrieved May 25, 2018, from http:// public.tableau.com/views/Jobs_34/JobsFinal?:embed=y\&:showVizH ome=no\&:host_url=https $\% 3 \mathrm{~A} \% 2 \mathrm{~F} \% 2 \mathrm{Fpublic}$.tableau.com $\% 2 \mathrm{~F} \&$ :embe d_code_version=3\&:tabs=no\&:toolbar=yes\&:animate_transition=yes\& :display_static_image=no\&:display_spinner=yes\&:display_overlay $=\mathrm{y}$ es\&:display_count=yes\&:loadOrderID=0

Permanent Forum on Indigenous Issues. (2012). 'Doctrine of Discovery', Used for centuries to justify seizure of indigenous land, subjugate peoples, must be repudiated by United Nations, Permanent Forum Told. In United Nations Economic and Social Council Eleventh Session, 3rd and 4th Meetings. New York, NY: Economic and Social Council. Retrieved from https://www.un.org/press/en/2012/hr5088.doc.htm

Quilgars, D., \& Pleace, N. (2016). Housing first and social integration: A realistic aim? Social Inclusion, 4(4), 5. https://doi.org/ 10.17645/ si.v4i4.672

Robinson, W. C. (2003). Risks and rights: the causes, consequences, and challenges of development-induced displacement (p. 102). Washington, DC: The Brookings Institution, SAIS Project on Internal Displacement. Retrieved from http://citeseerx.ist.psu.edu/ viewdoc/ download? doi=10.1.1.552.9873\&rep=rep1\&type $=$ pdf

Satiroglu, I. (2015). Development-induced displacement and resettlement: New perspectives on persisting problems. London, UK: Routledge.

Scruggs, G. (2018, May 15). Seattle passes scaled-back tax on Amazon, big companies. Reuters. Retrieved from https://www.reuters.com/ article/us-seattle-tax/seattle-city-council-backs-new-tax-on-largestcompanies-including-amazon-idUSKCN1IG002

Seattle City Council. (2018, May 14). Seattle Council passes tax on business to help address homelessness [Text and images]. Retrieved from https://www.seattle.gov/council/issues/progressive-tax-onbusiness

Sharma, R. (2016). Development Induced Displacement: A Study of population affected by Jaipur metro project (PhD Thesis). The ISS University, Jaipur, India. Retrieved from http://shodhganga.inflibnet.ac.in/ handle/10603/106025

Staff Reporter. (2018, June 2). Native organizations say new homeless American Indian and Alaska Natives not accurate in Seattle. Native 
News Online. Retrieved from https:// nativenewsonline.net/ currents/native-organizations-say-new-homeless-american-indianalaska-natives-not-accurate-in-seattle/

Stanley, J. (2011, August 11). Development-induced displacement and resettlement. Forced Migration Online. Retrieved from http:// www.forcedmigration.org/research-resources/expert-guides/ development-induced-displacement-and-resettlement

Stiles, M., \& Stewart, A. (2016, May 24). Google moving from Fremont to huge new South Lake Union space [Text and Images]. Retrieved June 15, 2018, from https://www.bizjournals.com/ seattle/ blog/ techflash/2016/03/google-moving-from-fremont-to-huge-new-southlake.html

Terminski, B. (2013). Development-Induced displacement and resettlement: theoretical frameworks and current challenges. Geneva, Switzerland: University of Geneva. Retrieved from https://dlc.dlib.indiana.edu/ dlc/bitstream/handle/10535/8833/Bogumil\%20Terminski,\%20devel opment-Induced \%20Displacement $\% 20$ and $\%$ 20Resettlement. $\% 20$ Theoretical \%20frameworks \%20and \%20current \%20challenges.pdf

The Innovation and Good Practice Team. (2013). Effective action to end homelessness: resettlement from homelessness services (NGO Report) (p. 27). London, UK: Homeless Link. Retrieved from https:// www.homeless.org.uk/sites/default/files/site-attachments/

Resettlement \%20guidance.pdf

Thrush, C.-P. (2017). Native Seattle: histories from the crossing-over place (2nd ed.). Seattle, WA: University of Washington Press. Retrieved from http://search.ebscohost.com/ login.aspx? direct=true\&scope $=$ site $\& \mathrm{db}=$ nlebk \&db=nlabk\&AN=1490845

Tran, S. K. (2017). GOOGLE: A reflection of culture, leader, and management. International Journal of Corporate Social Responsibility, 2(1), 1-14. https:/ / doi.org/10.1186/s40991-017-0021-0

Tsai, J., Mares, A. S., \& Rosenheck, R. A. (2012). Does housing chronically homeless adults lead to social integration? Psychiatric Services, 63(5), 427-434. https://doi.org/10.1176/appi.ps.201100047

Tucker, G. (1857). The history of the united states: from their colonization to the end of the twenty-sixth Congress, in 1841 (Vol. 1). Philadelphia, PA: J. B. Lippincott.

UN Habitat. (2016). Urbanization and development: emerging futures - key findings and messages (UN Document) (p. 49). Nairobi, Kenya: United Nations Settlement Programme. Retrieved from http://wcr.unhabitat.org/wp-content/uploads/2017/02/WCR2016_-Abridged-version-1.pdf 
United States Census Bureau. (2018). QuickFacts: Seattle city, Washington [Text and images]. Retrieved May 22, 2018, from https:// www.census.gov/quickfacts/fact/table/seattlecitywashington,US/P ST045216

United States Department of Housing and Urban Development Exchange. (2018). Housing First in permanent supportive housing. United States Department of Housing and Urban Development. Retrieved from https://www.hudexchange.info/resources/documents/HousingFirst-Permanent-Supportive-Housing-Brief.pdf

US Department of Commerce Bureau of Economic Analysis. (2017, September 20). Gross domestic product (GDP) by metropolitan area (millions of current dollars) [Text and images]. Retrieved from https:/ / www.bea.gov/iTable/iTable.cfm?reqid=70\&step=1\&isuri=1 $\&$ acrdn=3\#reqid $=70 \&$ step $=10 \&$ isuri $=1 \& 7003=200 \& 7035=-1 \& 7004$ $=$ naics $\& 7005=-1 \& 7006=42660 \& 7036=-1 \& 7001=2200 \& 7002=2 \& 7090=$ $70 \& 7007=2016 \& 7093=$ levels

Wamsley, L. (2017, May 10). New Amazon building in Seattle will include a homeless shelter. National Public Radio. Retrieved from https:// www.npr.org/sections/thetwo-way/2017/05/10/527801805/newamazon-building-in-seattle-will-include-a-homeless-shelter

Wood, G. S. (2009). Empire of liberty: a history of the early republic, 1789-1815. Oxford, UK: Oxford University Press.

Zuk, M., Bierbaum, A. H., Chapple, K., Gorska, K., Loukaitou-Sideris, A., Ong, P., \& Thomas, T. (2015). Gentrification, displacement and the role of public investment: A literature review (p. 76). Berkeley, CA: University of California Berkeley and University of California, Los Angeles. Retrieved from http://iurd.berkeley.edu/ uploads/ Displacement _Lit_Review_Final.pdf 